\title{
The peculiarities of motor fitness' classification model of 6-10 years old girls
}

\author{
Ivashchenko O.V. ${ }^{1}$, Iermakov S.S. ${ }^{2}$, Khudolii O.M. \\ ${ }^{1}$ H.S. Skovoroda Kharkiv National Pedagogical University, Ukraine \\ ${ }^{2}$ Gdansk University of Physical Education and Sport, Poland
}

\begin{abstract}
Purpose:

Material:

The purpose of the research is determination of motor fitness' classification model of 6-10 years old girls. in the research 6 years old girls $(n=36), 7$ years old girls $(n=48), 8$ years old girls $(n=57), 9$ years old girls $(n=38)$, 10 years old girls $(n=46)$ participated. Testing program includes commonly known tests.

Results: With age there happened some changes of coordination and power fitness, endurance, quickness, flexibility indicators. Suggested set of tests could be used for final control of girls' motor fitness.

Conclusions: In the process of analysis was calculated canonic coefficients of discriminant function (not standardized). These coefficients are multipliers of the set values of variables, which are components of discriminants functions. On the basis of them it is possible to classify girls by the level of motor fitness according to their age.

Keywords: $\quad$ motor abilities, discriminant analysis, classification model, girls.
\end{abstract}

\section{Introduction}

The problem of motor activity and health strengthening is rather relevant in Ukraine and in Europe. The scientists concentrate attention on innovative approaches to physical education, and also on realization of differentiated approach to physical education of children's and teenagers' $[1,2,4]$. Health improvement and rising of children's and teenagers' workability depends on optimal motor activity, which is ensured by physical education at school. The planning of educational process and integrative physical training of pupils provides the necessary amount of motor activity [11, 3 ].

The main task of school age children's physical education is teaching of motor actions $[4,17,30]$. The training process is regarded from the following positions: organization and educational management [11, 19, 35]; motivation for motor functioning (the higest level of exercise mastering provoques the large amount of motor activity [32, 21]). In educational process is investigated connection of training efficiency and motor functioning: successful education induces to increase motor activity's amount [14, 15]; cognitive and motor training emphasizes at nesessity to join the mental and motor components of motor fitness $[18,16]$. Special attention is paid on influence of motor fitness on study's effectiveness [ 33, 34, 29] and influence of physical loads on study's effectiveness [22, 28].

One of conditions of schoolchildren's physical education effectiveness is organization of pedagogic control at physical culture lessons [26, 27, 36]. Effectiveness of pedagogic control depends on the presence of object to be controlled and informative value of indicators, which characterize the changes of his/her state $[7,8,9]$. It was found that modeling is an effective method of receiving new information for realization of current and final control on the base of children's and teenagers' testing [6, 13, 23]. Factorial and discriminant analysis is one of methods of statistic modeling. Effectiveness of their application is illustrated by scientific data $[5,31,24]$. The mentioned works witness about demand in searching methodological approaches to solution motor fitness problem and its pedagogical control in schoolchildren.

It should examine the opportunity to use discriminant analysis for study peculiarities of motor fitness of 6-10 years old girls.

The purpose of the research is to determine motor fitness' classification model of 6-10 years old girls.

\section{Material and methods}

Participants: in the research 6 years old girls $(n=36)$, 7 years old girls $(n=48), 8$ years old girls $(n=57), 9$ years old girls $(n=38), 10$ years old girls $(n=46)$ participated.

Organization of the research: The following methods of the research were used: analysis of scientific literature, pedagogic testing and methods of mathematical statistic. Discriminant analysis was used as the method of modeling.

In testing program we included commonly known tests [23]. For assessment the girls' motor fitness we registered the results of the following motor tests: static stance on one foot (sec.); walking along segments of hexagon (steps); combined movements of arms, torso and legs (errors); walking along straight line after 5 rotations, deviations (cm); shuttle run $4 \times 9 \mathrm{~m}$ (sec.); $30 \mathrm{~m}$ run (sec.); frequency of arms' movements (times); catching of falling Dietrich's stick (cm); long jump from the spot (cm); 300 meters' run (sec.); arms' bending and unbending in mixed hanging on rope (times); torso rising in sitting position during 1 minute (times); torso bending from sitting position (cm); index assessment of backbone mobility; index assessment of shoulder joints' mobility.

Statistical analysis: processing of the research material was carried out with the help of IBM SPSS 20 program. Discriminant analysis helped to create prognostic model of belonging to group. This model builds discriminant function (or set of discriminant functions, if they are more than two) in the form of predictors-variables linear combination. It ensures the best groups' distribution. 
These functions are built basing on set of observations, belonging to groups of which is known. Further, these functions can be applied to new observations with known predictors-variables and unknown group belonging.

For every canonic discriminant function we calculated own value, dispersion percentage, canonic correlation, Wilks' Lambda, $\chi$ - Chi-square.

\section{Results}

The analysis permitted to determine, that statistically confident differences between mean group indicators were observed in the following below tests:

coordination abilities: in tests №№ 1-5 with age there are statistically confident differences in results of testing. Results improves in test № 1 «Static stance on one foot (sec.)» $(\mathrm{p}<0,001)$, test № 2 «Walking along segments of hexagon (steps)» $(\mathrm{p}<0,001)$, test № 4 «Walking along straight line after 5 rotations, deviations $(\mathrm{cm}) »(\mathrm{p}<0,001)$, test № 5 «Shuttle run $4 \times 9 \mathrm{~m}$ (sec.)» $(\mathrm{p}<0,001)$, test № 3 «Combined movements of arms, torso and legs (errors)» $(\mathrm{p}<0,1)$. The least dynamics of results is observed in test № 3. The exercises of combined movements of arms, torso and legs are difficult for 6-10 year old girls;

quickness: in tests for different demonstration of quickness with age is observed statistically confident dynamics. Results improves in test № 6 «30 m run» (p $<0,001$ ), test № 7 «Frequency of arms' movements» ( $p$ $<0,001$ ), test № 8 №21 «Catching of falling Dietrich’s stick $(\mathrm{cm}) »(\mathrm{p}<0,001)$. The most dynamics of results is observed in test № 6 «30 m run»;

power abilities: in tests № 9 «Long jump from the spot $(\mathrm{cm})$ » $(\mathrm{p}<0,001)$, № 11 «Arms' bending and unbending in mixed hanging on rope (times)» $(\mathrm{p}<0,001)$, is observed statistically confident dynamics of results;

endurance: in tests № 10 «300 meters’ run» ( $p<$ 0,001 ), № 12 «Torso rising in sitting position during 1 minute (times)» $(\mathrm{p}<0,001)$ is observed statistically confident dynamics of results;

flexibility: in tests №№ 14-15 with age is observed statistically positive confident dynamics of testing results, in test № 13 «Torso bending from sitting position $(\mathrm{cm})$ » dynamics of results isn't statistically confident.

Thus, with age there are differences in indicators of coordination and power fitness, endurance, quickness, flexibility. Suggested set of tests could be used for final control of motor fitness of 6-10 years old girls.

The results of discriminant analysis indicate, that first canonic function explains variation of results by $85,3 \%$, the second - by $8,1 \%$. It witnesses about their high informational potential. Correlation coefficient between calculated values of discriminant function and indicators of belonging to group equal to $r=0,831$. It witnesses about high prognostic potential of first canonic function. The first canonic function's own value witnesses about successfully selected coefficients in it.

The analysis of canonic functions points that first and second functions have high discriminant potential and meaning in interpretation in respect to general communality $(\lambda=0,216$ and statistical significance $\mathrm{p}=0,001$ for all set of canonic functions).

Normalized coefficients of canonic discriminant function give opportunity to define correlation of variables' contribution in function result.

1. The highest contribution in the first canonic function is provided by the following variables:

Shuttle run $4 \times 9 \mathrm{~m}-, 552$;

Catching of falling Dietrich's stick - ,343;

Walking along segments of hexagon (steps) - -,344;

300 meters' run - ,329;

2. The highest contribution in the second canonic function is provided by the following variables:

Combined movements of arms, torso and legs - -,577;

Long jump from the spot - ,553;

Static stance on one foot - ,522;

Frequency of arms' movements - -,424;

3. The highest contribution in the third canonic function is provided by the following variables:

Shuttle run $4 \times 9 \mathrm{~m}-, 717$;

Index assessment of backbone mobility - ,604;

Frequency of arms' movements - ,488;

4. The highest contribution in the fourth canonic function is provided by the following variables:

Index assessment of shoulder joints' mobility - ,627;

Long jump from the spot - -,615;

Torso rising in sitting position during 1 minute - ,507.

On the basis of results of variables from the first list could classify $6-10$ years old girls, from the second list $7-10$ years old girls; from the third list $-8-10$ years old girls; from the fourth list $-9-10$ years old girls.

It is determined, that maximum discriminant potential have first and second functions. That's why variables from the first and second lists play the main role in classification.

Structural coefficients of canonic discriminant function are correlation coefficients of variables with function. They determine the influence power of independent variables on dependent.

1. The maximum influence power of independent variables on dependent in the fist function have:

Shuttle run $4 \times 9 \mathrm{~m}$ (sec.) - ,715;

300 meters' run,- 531 ;

$30 \mathrm{~m}$ run,- 477 ;

Long jump from the spot - -,462;

Catching of falling Dietrich's stick - ,385;

Walking along segments of hexagon (steps) --,228;

2. The maximum influence power of independent variables on dependent in second function have:

Static stance on one foot - ,363;

Combined movements of arms, torso and legs - -,351;

3 . The maximum influence power of independent variables on dependent in third function have:

Frequency of arms' movements - ,384;

Index assessment of backbone mobility - ,377;

Arms' bending and unbending in mixed hanging on rope (times) - -,202;

Torso bending from sitting position - ,135;

4. The maximum influence power of independent variables on dependent in fourth function have: 
Index assessment of shoulder joints' mobility - ,596;

Walking along straight line after 5 rotations, deviations ,-- 342 ;

Torso rising in sitting position during 1 minute - ,331.

The analysis of correlation coefficients determines, that for 6-10 years old girls is significant the complex development of motor abilities; for 7-10 years old girls the attention is paid on development of coordination abilities; for 8-10 years old girls - on quickness, power and flexibility; for 9-10 years old girls - on flexibility, motor coordination and power endurance.

In table №1 the canonic (unnormalized) coefficients of discriminant function are given, which are multipliers of the set values discriminant functions. On the basis of comparison of obtained data with function's centrodes (table №2) it is possible to classify each particular case. The results of classification are given in table №3. 59,8\% of output group observations were classified correctly. It made possible to claim that classification of 6-10 years old girls is possible according to suggested set of tests.

\section{Discussion}

The obtained results supplement the data about methodological approaches to the pedagogical control of motor abilities development [37, 35]. The results extend opportunities of modeling in the process of new information's receiving about dynamics of motor abilities development of children [37, 29]. The effective use of factorial and discriminant analysis in determination of motor fitness structure of children and teenagers is proved $[10,20,25]$. The received data is important for estimation of primary school age readiness to study motor fitness. They complete data about influence of motor fitness' development level on study's effectiveness [12, 35]. They

Table 1. Unnormalized coefficients of canonic discriminant function. 6-10 years old girls

\begin{tabular}{|c|c|c|c|c|c|}
\hline \multirow{2}{*}{ Test title } & \multicolumn{5}{|l|}{ Age } \\
\hline & 6 & 7 & 8 & 9 & 10 \\
\hline Static stance on one foot (sec.) &,- 003 & ,081 &,- 007 & ,022 &,- 003 \\
\hline Walking along segments of hexagon (steps) &,- 154 &,- 019 &, 008 & ,002 &,- 154 \\
\hline $\begin{array}{l}\text { Combined movements of arms, torso and legs } \\
\text { (errors) }\end{array}$ & ,057 & -,189 &,- 029 & ,059 & ,057 \\
\hline $\begin{array}{l}\text { Walking along straight line after } 5 \text { rotations, } \\
\text { deviations }(\mathrm{cm})\end{array}$ &, 000 & ,001 &,- 004 &,- 005 &, 000 \\
\hline Shuttle run $4 \times 9 \mathrm{~m}$ (sec.) & ,500 & ,364 & 649 &,- 071 & ,500 \\
\hline 30 m run (sec.) & ,366 & 202 &,- 342 & ,007 & ,366 \\
\hline Frequency of arms' movements (times) &,- 017 &,- 040 &, 046 &,- 002 &,- 017 \\
\hline Catching of falling Dietrich's stick (cm) & 047 &,- 016 & 017 & 015 & 047 \\
\hline Long jump from the spot $(\mathrm{cm})$ & ,002 & ,030 & ,013 &,- 033 &, 002 \\
\hline 300 meters' run (sec.) & ,019 &,- 015 &,- 023 &,- 006 & ,019 \\
\hline $\begin{array}{l}\text { Arms' bending and unbending in mixed hanging on } \\
\text { rope (times) }\end{array}$ &,- 005 &,- 013 &,- 047 & ,018 &,- 005 \\
\hline $\begin{array}{l}\text { Torso rising in sitting position during } 1 \text { minute } \\
\text { (times) }\end{array}$ &,- 013 & 019 &, 005 & ,055 &,- 013 \\
\hline Torso bending from sitting position $(\mathrm{cm})$ & ,010 &,- 019 & ,058 &, 040 & ,010 \\
\hline Index assessment of backbone mobility & ,015 &,- 036 & ,080 &,- 004 & ,015 \\
\hline Index assessment of shoulder joints' mobility & ,392 & ,705 &,- 190 & 1,760 & ,392 \\
\hline (Constant) & $-13,463$ & $-6,996$ & $-9,522$ &,- 255 & $-13,463$ \\
\hline
\end{tabular}

Table 2. Functions in groups' centrodes. 6-10 years old girls

\begin{tabular}{lllll}
\hline Girls' age & Function & & & $\mathbf{3}$ \\
\hline 6 years & $\mathbf{1}$ & $\mathbf{2}$ &, 173 &, 054 \\
7 years & 2,843 &, 501 &,- 481 &, 083 \\
8 years &, 632 &,- 575 &, 139 &,- 277 \\
9 years &,- 239 &,- 132 &, 610 &, 191 \\
10 years & $-1,085$ &,- 293 &,- 306 &, 050 \\
\hline
\end{tabular}


Table 3. Results of groups' classification. 6-10 years old girls

\begin{tabular}{|c|c|c|c|c|c|c|c|}
\hline \multirow{2}{*}{ Index } & \multirow{2}{*}{ Girls' age } & \multicolumn{5}{|c|}{ Predicted belonging to group } & \multirow{2}{*}{ Total } \\
\hline & & 6 years & 7 years & 8 years & 9 years & 10 years & \\
\hline \multirow{5}{*}{ Frequency } & 6 years & 30 & 6 & 0 & 0 & 0 & 36 \\
\hline & 7 years & 4 & 27 & 15 & 1 & 1 & 48 \\
\hline & 8 years & 4 & 9 & 28 & 7 & 8 & 56 \\
\hline & 9 years & 0 & 1 & 13 & 15 & 9 & 38 \\
\hline & 10 years & 0 & 0 & 4 & 8 & 34 & 46 \\
\hline \multirow{5}{*}{$\%$} & 6 years & 83,3 & 16,7 & 0 & 0 & 0 & 100,0 \\
\hline & 7 years & 8,3 & 56,3 & 31,3 & 2,1 & 2,1 & 100,0 \\
\hline & 8 years & 7,1 & 16,1 & 50,0 & 12,5 & 14,3 & 100,0 \\
\hline & 9 years & 0 & 2,6 & 34,2 & 39,5 & 23,7 & 100,0 \\
\hline & 10 years & 0 & 0 & 8,7 & 17,4 & 73,9 & 100,0 \\
\hline
\end{tabular}

also point at necessity of power abilities development [20, 25].

In the process of analysis was calculated canonic coefficients of discriminant function (not standardized). These coefficients are multipliers of the set values of discriminant functions. On this base it is possible to classify girls by the level of motor fitness according to their age and it is of practical significance.

\section{Conclusions}

So, discriminant analysis permitted to answer the question: how confidently it is possible to separate one form from other by set of offered variables; which of variables influence most significantly on separation of forms; to which form object belongs on the base of discriminant variables' values.

The suggested set of tests could be used for final

\section{References}

1. Piccinno Andrea, Colella Dario. Physical fitness level in Italian high-school adolescents: a cross-sectional study. Journal of Physical Education and Sport, 2014; 14 (3): 431437.

2. Coskun Ali, Sahin Gulsah. Two different strength training and untrained period effects in children. Journal of Physical Education and Sport, 2014; 14(1): 42-46.

3. Bodnar I. Integrative physical education of different health groups' schoolchildren. Lviv: LSUPC; 2014. (in Ukrainian)

4. Vas'kov IuV. Innovative approaches to organization of comprehensive educational establishments' pupils physical education. Teoria ta metodika fizichnogo vikhovannia, 2016;4:5-12. doi:10.17309/tmfv.2016.4.1174 (in Ukrainian)

5. Vlasov A, Demichkovs'kij A, Ivashchenko O, Lopat'iev A, Pitin M, P'ianilo Ia, Khudolii O. Systemic approach and mathematical modeling of biological and natural objects and processes. Fiziko-matematichne modeliuvannia ta informacijni tekhnologii, 2016;23:17-28. (in Ukrainian)

6. Ivashchenko OV, Shepelenko GP. Comparative characteristics of Coordination fitness and power of middle class. Teoria ta metodika fizichnogo vikhovannia, 2014;2:2230. doi:10.17309/tmfv.2014.2.1096 (in Ukrainian) control of motor fitness of 6-10 years old girls.

On the basis of canonic coefficients of discriminant function is possible to classify pupils by the level of motor fitness according to the girls' age, which has practical importance for effective development of physical training programs of primary school age children.

\section{Acknowledgements}

The study has been fulfilled in compliance with plan of scientific-research works of Ministry education and science, youth and sports of Ukraine by topic 13.04. “Modeling of children's and adolescents' motor abilities' training and development" (2013-2014) (state registration number is 0113U002102).

\section{Conflict of interests}

The author declares that there is no conflict of interests.

7. Ivashchenko OV, Mushketa R, Khudolii OM, Iermakov SS. Characteristic force preparedness boys 6-7 grades. Teoria ta metodika fizichnogo vikhovannia, 2014;3:17-24. doi:10.17309/tmfv.2014.3.1104 (in Ukrainian)

8. Ivashchenko OV, Pashkevich SA, Krinin IuV. Comparative characteristics of functional coordination and force readiness boys $8-9$ grades. Teoria ta metodika fizichnogo vikhovannia, 2014;2:31-39. doi:10.17309/tmfv.2014.2.1099 (in Ukrainian)

9. Ivashchenko OV, Ceslicka M, Khudolii OM, Iermakov SS. Modeling power fitness girls grades 6-7. Teoria ta metodika fizichnogo vikhovannia, 2014;3:10-16. doi:10.17309/ tmfv.2014.3.1103 (in Ukrainian)

10.Kozina Zh. Theoretical principles and results of systemic analysis practical application in scientific researches of sport games. Teoria ta metodika fizicnogo vihovanna, 2007; 6:1518. (in Ukrainian)

11.Krucevich T, Trachuk S, Napadij A. Planning of physical culture training process for secondary comprehensive schools' pupils. Teoriia i metodika fizichnogo vikhovannia $i$ sportu, 2016;1:36-42. (in Ukrainian)

12.Repko E, Kozin S, Kostyrko A. Training of pre school age and junior school age children to motor actions on the base of their psychological and physical characteristics on example 
of rock climbing. Zdorov'e, sport, reabilitaciia, 2016; 2:4650.

13.Khudolii OM, Ivashchenko OV. Features functional coordination force preparedness and girls grades 7-8. Teoria ta metodika fizichnogo vikhovannia, 2014;2:15-21. doi:10.17309/tmfv.2014.2.1095

14.Al-Ravashdeh Abdel Baset, Kozina ZL, Bazilyuk TA, Ilnickaya AS. Methodic of senior pupils' training to throwing movements on the bases of technology of complex impact on motor and intellectual development. Pedagogics, psychology, medical-biological problems of physical training and sports, 2015;19 (11), 3-10. doi:10.15561/18189172.2015.1101

15.Al-Ravashdeh Abdel Baset, Kozina Zh.L., Bazilyuk T.A., Ilnickaya, A.S. Influence of motor skills' training methodic on senior pupils' speed-power and endurance qualities at light athletic trainings with aplication of interdisciplinary connections. Pedagogics, psychology, medical-biological problems of physical training and sports, 2015; 19(10):3-10. doi:10.15561/18189172.2015.1001

16.Altunsoz IH, Goodway JD. Skiping to motor competence: the influence of project successful kinesthetic instruction for preschoolers on motor competence of disadvantaged preschoolers. Physical Education and Sport Pedagogy, 2016;21(4): 366-385. doi:10.1080/17408989.2015.1017453

17.Arziutov G, Iermakov S, Bartik P, Nosko M, Cynarski WJ. The use of didactic laws in the teaching of the physical elements involved in judo techniques. Ido Movement for Culture, 2016;16(4):21-30. doi:10.14589/ido.16.4.4

18.Chatzipanteli A, Digelidis N, Karatzoglidis C, Dean R. A tactical-game approach and enhancement of metacognitive behaviour in elementary school students. Physical Education and Sport Pedagogy, 2016;21(2):169-184. doi:10.1080/174 08989.2014 .931366

19. Chernenko SO. Effectieness of junior form pupils' training of gymnastic exercises in different modes of their fulfillment. Pedagogics, psychology, medical-biological problems of physical training and sports, 2015;19(8):65-74. doi:10.15561/18189172.2015.0809

20.Cieślicka M, Ivashchenko O. Features of formation of the cumulative effect of power loads in boys 7 years old. Journal of Education, Health and Sport, 2017;7(1):198-208. doi:10.5281/zenodo. 250599

21.Darnis F, Lafont L. Cooperative learning and dyadic interactions: two modes of knowledge construction in socioconstructivist settings for team-sport teaching. Physical Education and Sport Pedagogy, 2015;20(5):459-473. doi:1 0.1080/17408989.2013.803528

22.Ivashchenko OV, Kapkan OO. Simulation of process of 14 15 years old girls' training of light athletic and gymnastic exercises. Pedagogics, psychology, medical-biological problems of physical training and sports, 2015;19(8):32-39. doi:10.15561/18189172.2015.0805

23.Ivashchenko O, Khudolii O, Yermakova T, Iermakov S, Nosko M, Nosko Y. Factorial and discriminant analysis as methodological basis of pedagogic control over motor and functional fitness of 14-16 year old girls. Journal of Physical Education and Sport, 2016;16(2):442 - 451. doi:10.7752/ jpes.2016.02068
24.Ivashchenko O, Khudolii O, Iermakov S, Lochbaum MR, Cieslicka M, Zukow W, et al. Intra-group factorial model as the basis of pedagogical control over motor and functional fitness dynamic of 14-16 years old girls. Journal of Physical Education and Sport, 2016;16(4):1190 - 1201

25.Ivashchenko O, Cieślicka M. Features of evaluations of power loadsin boys 7 years old. Journal of Education, Health and Sport, 2017;7(1):175-183. doi:10.5281/zenodo.249184

26.Ivashchenko OV. Methodic of pedagogic control of 1617 years' age girls' motor fitness. Pedagogics, psychology, medical-biological problems of physical training and sports, 2016;20(5):26-32. doi:10.15561/18189172.2016.0504

27.Ivashchenko OV, Kapkan OO. Informative pedagogic control indicators of 14-15 years age girls' motor fitness. Pedagogics, psychology, medical-biological problems of physical training and sports, 2016;20(6):18-25. doi:10.15561/18189172.2016.0603

28.Kapkan OO. Features of 14-15 years' age boys' training to physical exercises. Pedagogics, psychology, medicalbiological problems of physical training and sports, 2015;19(9):26-32. doi:10.15561/18189172.2015.0904

29.Khudolii OM. Theoretical-methodic principles of system of junior, 7-13 yrs. age, gymnasts' training. Dokt. Diss., Kiev; 2011. (in Ukrainian)

30.Khudoli OM, Ivashchenko OV, Chernenko SO. Simulation of junior shcoolchildren's training to acrobatic exercises and vaults. Pedagogics, psychology, medical-biological problems of physical training and sports, 2015;19(7):64-71. doi:10.15561/18189172.2015.0709

31.Khudolii OM, Ivashchenko OV, Iermakov SS, Rumba OG. Computer simulation of junior gymnasts' training process. Science of Gymnastics Journal, 2016;8;(3):215-228.

32.Xu X, Ke F. From psychomotor to 'motorpsycho': Learning through gestures with body sensory technologies. Educational Technology Research and Development, 2014;62;(6):711741. doi:10.1007/s11423-014-9351-8

33.Ivashchenko OV. Special aspects of motor fitness influence on level of 11-13 years' age girls' physical exercises' mastering. Pedagogics, psychology, medical-biological problems of physical training and sports, 2017; 21(1): 11-17. doi:10.15561/18189172.2017.0102

34.Ivashchenko OV. Classification of 11-13 yrs girls' motor fitness, considering level of physical exercises' mastering. Pedagogics, psychology, medical-biological problems of physical training and sports, 2017; 21(2): 65-70. doi:10.15561/18189172.2017.0203

35.Ivashchenko OV. Modelling of physical education students. Kharkiv: OVS. 2016: 360.

36.Lopatiev A, Ivashchenko O, Khudolii O, Pjanylo Y, Chernenko S, Yermakova T. Systemic approach and mathematical modeling in physical education and sports. Journal of Physical Education and Sport, 2017; 17 (1): 146155.

37.Ivashchenko OV. Special aspects of motor abilities development in 6-10 years' age girls. Pedagogics, psychology, medical-biological problems of physical training and sports, 2017; 21(3): 105-110. doi:10.15561/18189172.2017.0302 
Information about the authors:

Ivashchenko O.V.; http://orcid.org/0000-0002-2708-5636; tmfv@tmfv.com.ua; H.S. Skovoroda Kharkiv National Pedagogical University; Alchevskyh str. 29, Kharkiv, 61002, Ukraine.

lermakov S.S.; http://orcid.org/0000-0002-5039-4517; sportart@gmail.com; Gdansk University of Physical Education and Sport; Kazimierza Gorskiego 1, 80-336 Gdansk, Poland.

Khudolii O.M.; http://orcid.org/ 0000-0002-5605-9939; tmfv@tmfv.com.ua; H.S. Skovoroda Kharkiv National Pedagogical University; Alchevskyh str. 29, Kharkiv, 61002, Ukraine.

Cite this article as: Ivashchenko OV, Iermakov SS, Khudolii OM. The peculiarities of motor fitness' classification model of 6-10 years old girls. Pedagogics, psychology, medical-biological problems of physical training and sports, 2017;21(6):260-265. doi:10.15561/18189172.2017.0601

The electronic version of this article is the complete one and can be found online at: http://www.sportpedagogy.org.ua/index.php/PPS/issue/archive

This is an Open Access article distributed under the terms of the Creative Commons Attribution License, which permits unrestricted use, distribution, and reproduction in any medium, provided the original work is properly cited (http://creativecommons.org/licenses/by/4.0/deed.en).

Received: 11.06.2017

Accepted: 02.07.2017; Published: 05.11.2017 